\title{
The Potential Distance of Highly Pathogenic Avian Influenza Virus Dispersal by Mallard, Common Teal and Eurasian Pochard
}

\author{
Anne-Laure Brochet, ${ }^{1,2}$ Matthieu Guillemain, ${ }^{2}$ Camille Lebarbenchon, ${ }^{1,3}$ Géraldine Simon, ${ }^{1}$ \\ Hervé Fritz, ${ }^{4}$ Andy J. Green, ${ }^{5}$ François Renaud, ${ }^{3}$ Frédéric Thomas, ${ }^{3}$ and Michel Gauthier-Clerc ${ }^{1}$ \\ ${ }^{1}$ Centre de Recherche de La Tour du Valat, Le Sambuc, 13200 Arles, France \\ ${ }^{2}$ Office National de la Chasse et de la Faune Sauvage, Unité Sanitaire de la Faune, 01330 Birieux, France \\ ${ }^{3}$ GEMI, UMR CNRS/IRD 2724, IRD, 911 Avenue Agropolis, BP 64501, 34394 Montpellier Cedex 5, France \\ ${ }^{4}$ Université de Lyon, Université Claude Bernard Lyon 1, CNRS UMR 5558 Biométrie et Biologie Evolutive, Bâtiment 711, \\ 43 Bd du 11 novembre 1918, 69622 Villeurbanne Cedex, France \\ ${ }^{5}$ Department of Wetland Ecology, Estación Biológica de Doñana-CSIC, C/ Américo Vespucio s/n, 41092 Sevilla, Spain
}

Abstract: Waterbirds represent the major natural reservoir for low pathogenic (LP) avian influenza viruses (AIV). Among the wide diversity of subtypes that have been described, two of them (H5 and H7) may become highly pathogenic (HP) after their introduction into domestic bird populations and cause severe outbreaks, as is the case for HP H5N1 in South-Eastern Asia. Recent experimental studies demonstrated that HP H5N1 AIV infection in ducks does not necessarily have significant pathological effects. These results suggest that wild migratory ducks may asymptomatically carry HP AIV and potentially spread viruses over large geographical distances. In this study, we investigated the potential spreading distance of HP AIV by common teal (Anas crecca), mallard (A. platyrhynchos), and Eurasian pochard (Aythya ferina). Based on capture-mark-recapture method, we characterized their wintering movements from a western Mediterranean wetland (Camargue, South of France) and identified the potential distance and direction of virus dispersal. Such data may be crucial in determining higher-risk areas in the case of HP AIV infection detection in this major wintering quarter, and may serve as a valuable reference for virus outbreaks elsewhere.

Keywords: influenza A virus, wild ducks, dispersal, risk areas, wetlands, H5N1

\section{INTRODUCTION}

Wild ducks are traditionally considered as natural reservoirs of low pathogenic (LP) avian influenza viruses (AIV) (Webster et al., 1992). These birds play an important role in

Correspondence to: Anne-Laure Brochet, e-mail: anne-laure.brochet@oncfs.gouv.fr the ecology and propagation of these viruses (Olsen et al., 2006). For instance, in Southern Europe, approximately $1-5 \%$ of migratory mallard (Anas platyrhynchos) and other dabbling ducks are infected with LP AIV, particularly during winter (De Marco et al., 2003; Lebarbenchon et al., 2007, in press). Although their precise role in the dispersal of highly pathogenic (HP) AIV is still under debate (Gauthier-Clerc et al., 2007; Kilpatrick et al., 2006; Gilbert et al., 2006), observations such as the one that occurred in 
March 2006 in western Europe suggest that wild ducks have been implicated in recent HP H5N1 outbreaks (Feare, 2007; Globig et al., 2009; Nagy et al., 2009). Governments and the poultry industry therefore need information on migratory duck species that can carry HP AIV to help them take appropriate measures in case of an outbreak, in particular to define a risk area around an outbreak for a period of several weeks. These risk areas are dependent upon the duration of viral excretion and persistence in the environment, as well as upon the movement of wild ducks in terms of direction (azimuth from the outbreak) and distance.

Studies performed on wild ducks experimentally infected with HP H5N1 AIV have recently demonstrated that birds generally excreted viruses for up to 6 days postinfection, without strong clinical or pathological effects (Brown et al., 2006; Keawcharoen et al., 2008). Other studies, performed specifically on mallards (Hulse-Post et al., 2005; Sturm-Ramirez et al., 2005) also have shown that some individual birds excreted the virus during a prolonged period for up to 21 days. Even though these studies have been performed under laboratory conditions, long-term shedding, combined with the fact that the experimental infection does not always induce strong physiological and behavioral effects, suggest that migratory ducks may act as an efficient vector of HP AIV in the wild (see Weber and Stilianakis, 2007; Lebarbenchon et al., 2009 for discussion).

Most ducks are migratory species that make long displacements during fall and spring migration, between their breeding and wintering areas (Alerstam, 1990; Green, 1996). During winter, ducks also can move over shorter distances, (i.e., hundreds of kilometers) to switch wintering quarters according to weather conditions (Ridgill and Fox, 1990). We focused on mallard, common teal (Anas crecca), and Eurasian pochard (Aythya ferina) because of their potential roles in HP AIV dispersal (Keawcharoen et al., 2008), their abundance in Europe, and their migratory behavior (Cramp and Simmons, 1977; Delany and Scott, 2006). In this study, we made the assumption that these three duck species can be "healthy carriers" of HP AIV during their displacements between wetlands during winter.

Mediterranean wetlands represent key wintering grounds for ducks in the western Palearctic region and are important stop-over sites for birds migrating from western Europe to North Africa (Jourdain et al., 2007). We focused on the Camargue area, an alluvial lowland covering some
140,000 ha in the Rhone Delta (south of France), where hundreds of thousands of wild ducks spend the winter or stop to forage during migrations (Tamisier and Dehorter, 1999).

This study was designed to determine the potential and maximal risk-area of HP AIV dispersal from the Camargue, during winter, by three species of wild ducks (mallard, common teal, and Eurasian pochard). We assessed the distance and direction of movements of these species from the Camargue area according to winter month and time elapsed after a potential outbreak, using capture-mark-recapture data, based on ringing data. Ringing-recovery data currently provide the best method to study bird movements, in terms of cost/efficiency ratio, but they require long-term studies to ensure the accumulation of sufficient recovery data (Jourdain et al., 2007).

\section{Methods}

We used a long-term population study of ducks, which was performed in the Camargue (southern France) between January 1952 and February 1978. In total, 59,087 ducks were ringed at "la Tour du Valat" $\left(43^{\circ} 30^{\circ} \mathrm{N}, 4^{\circ} 40^{\circ} \mathrm{E}\right)$. The duck ringing season generally began in September and ended in March. Ducks were caught using standard dabbling duck funnel traps hidden in the vegetation (Bub, 1991). All birds were fitted with a numbered metal ring upon capture, allowing individual recognition later upon ring recovery. Ring recovery data were obtained when ringed birds were recaptured alive (5.2\%), hunted (85.3\%), or found dead (9.2\%). Only $0.3 \%$ of recoveries had an unknown origin. The three duck species are widely hunted in Europe, and $75.7 \%, 73.9 \%$, and $87.3 \%$ of recoveries were by hunting for mallard, Eurasian pochard, and common teal, respectively. Only birds recovered within 1 month after ringing and before March 31st of the ringing season were considered (i.e., spring and summer recoveries + inter-annual recoveries were discarded) to limit the study to winter movements from a known area.

For each recovery, the distance and azimuth from the ringing site were calculated (mallard: $n=202$; Eurasian pochard: $n=46$; common teal: $n=1,244$ ). Average distance and azimuth were then computed per 10-day period until 1 month after ringing. We calculated the "average" azimuth by using Cartesian coordinates. Thus, this average was not affected by rotation direction of angular measurements. 
The distribution of distance values was non-normal (Shapiro tests: all $\mathrm{W}$ values $>0.347$, all $\mathrm{P}$ values $<0.001$ ), even after usual transformations (e.g., logarithm or squareroot). We first performed correlation analyses between distance travelled and time elapsed since ringing for each duck species by using Spearman's tests. Second, we tested the effect of duck species, month and year of ringing on the distance between recovery and ringing places, by using a Generalized Linear Model (GLM) with quasi-Poisson distribution. A backwards stepwise model selection procedure was used, gradually removing nonsignificant terms (at $P=0.05)$ from the most complete model. The extent to which our final model fitted the data was assessed by the ratio of the residual deviance to the number of degrees of freedom (the ideal ratio was 1; Crawley, 1993). Third, we compared proportions of recoveries found outside the Camargue (i.e., at a distance $>20 \mathrm{~km}$ from the ringing location) between three periods of the winter (September to October: fall migration; November to January: midwinter; February to March: spring migration) by using Fisher's exact tests. R software (version 2.8.1) was used for all statistical analyses (R Development Core Team, 2008) and results are presented in the form of mean \pm standard-error.

\section{RESULTS}

The average distances and azimuths of recovery during the first 30 days after ringing are summarized in Fig. 1, for each duck species and each month of ringing (see Appendix for results computed per 10-day period until 1 month after ringing). For example, in February, for mallard, the median distance of ring recovery was $3 \mathrm{~km}$ westward after 10 days and $200 \mathrm{~km}$ eastward after 30 days. For Eurasian pochard, shorter distances of $2 \mathrm{~km}$ eastward after 10 days and $20 \mathrm{~km}$ north-eastward after 30 days were observed. Finally, for common teal longer distances of $20 \mathrm{~km}$ after 10 days and $280 \mathrm{~km}$ after 30 days, both in an eastward direction, were recorded. Overall, the distance travelled by birds increased with time elapsed since ringing for mallard and common teal (Spearman tests: $r_{s}=0.20, P=0.005$, and $r_{s}=0.28$, $P<0.001)$. This correlation was not significant for Eurasian pochard $\left(\mathrm{r}_{\mathrm{s}}=0.07, \mathrm{P}=0.667\right)$.

The final model of the stepwise backwards selection procedure retained duck species and month of ringing, which both had significant effects (Table 1). This model provided a reasonably good fit to the data: deviance was equal to 3,566.75, and degrees of freedom was 1,489 (ratio,
2.4). Common teal covered significantly more distance than mallard and Eurasian pochard (Mann-Whitney $U$ tests: mallard-teal, $\quad W=68,222, \quad P<0.001 ;$ pochard-teal, $\mathrm{W}=16,443, \mathrm{P}<0.001 ;$ mallard-pochard, $\mathrm{W}=4,334$, $\mathrm{P}=$ 0.473; Fig. 2). Common teal covered significantly more distance in 30 days toward the end of the winter season than they did at the beginning (Spearman test: $r_{s}=0.14$, $\mathrm{P}<0.001$ ). The opposite was observed for Eurasian pochard, which covered significantly shorter distances in 30 days as winter progressed $\left(r_{s}=-0.49, P<0.001\right)$, whereas the correlation was not significant for mallard $\left(r_{s}=0.05, P=0.470\right.$; Fig. 3$)$.

During the whole winter period, $19 \%$ and $17 \%$ of mallards and Eurasian pochards were respectively recovered outside the Camargue, i.e., at a distance $>20 \mathrm{~km}$ from the ringing place. In contrast, this proportion was $54 \%$ in common teal (Table 2). For the latter species, this proportion differed significantly between three periods of the winter (September to October: fall migration; November to January: midwinter; February to March: beginning of spring migration; Fisher's test: $P=0.026$ ). The proportion of individuals recovered outside the Camargue was greatest during midwinter (25\%, 55\%, and $53 \%$ for the three winter periods, respectively). For both mallard and Eurasian pochard, this proportion was not significantly different between the three winter periods (all $P$ values $>0.41$ ). The same results were obtained for all species when only the hunting recoveries were used in the analyses (results not shown).

Despite these differences (between species and in time), it is possible to draw high-risk directions from the ringing site according to the month of ringing, through the analysis of the recoveries occurring during the 30 days after ringing (Fig. 1). For mallard and Eurasian pochard, if ringed in September and October, individuals principally remained in the Camargue, at a mean distance of $11 \pm 2 \mathrm{~km}$ and $5 \mathrm{~km}$ respectively from the ringing site (note only one Eurasian pochard recovery in October). In contrast, for common teal ringed during the same period, some individuals moved over long distances, for instance at a mean distance of $197 \pm 144 \mathrm{~km}$. When ringed from November to January, individuals of the three species could later be recovered in any direction, but at different distances (mean distance in km: mallard, $28 \pm 6$; Eurasian pochard, $35 \pm 15$; common teal, $151 \pm 7$ ). These movements suggest a high turnover between winter quarters, especially for common teal. Finally, after having been ringed in February or March, all three species tended to move toward a single direction, the 
a
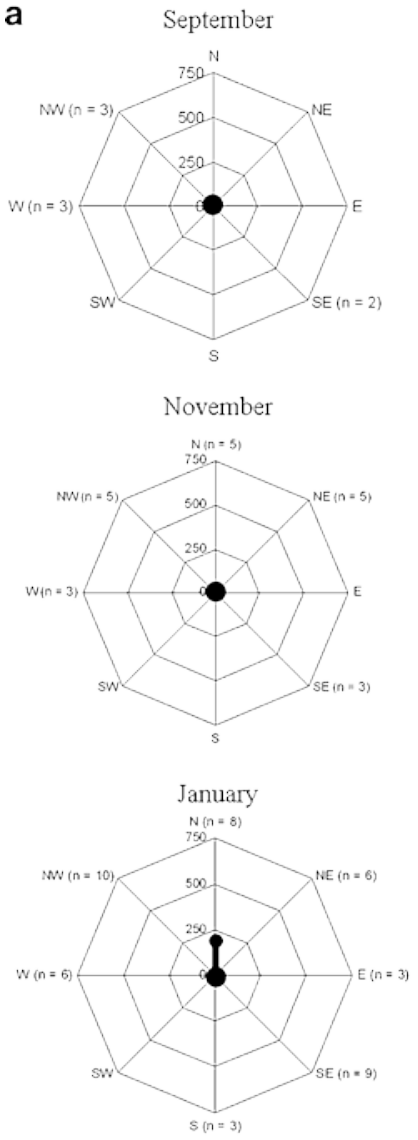

March

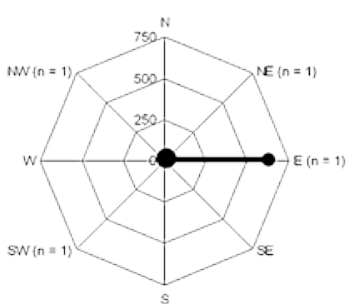

b
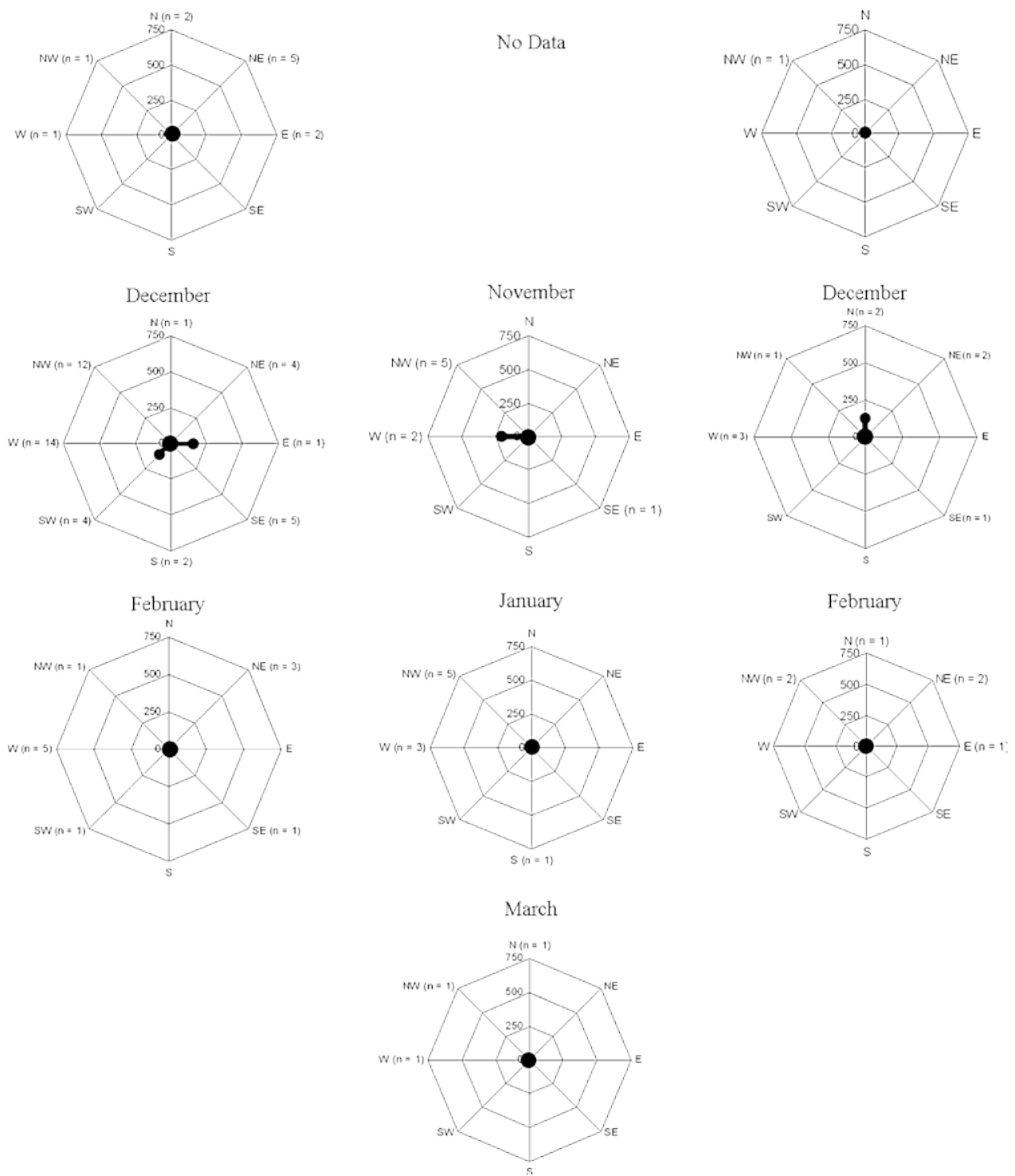

Figure 1. Median distance (in km, indicated on the North axis) and number of recoveries (n), according to 8 principal directions, during the 30 days after ringing and for each winter month for (a) mallard, (b) Eurasian pochard, and (c) common teal. The black area indicates how far away and in which directions birds were recovered in each case.

North-East, but still at different average distances (mean distances in km: mallard, $51 \pm 33$; Eurasian pochard, $5 \pm 2$; common teal, $193 \pm 14$ ). This direction corresponds to their most likely spring migration route.

\section{DISCUSSION}

Among the three species studied, common teal travelled the longest distances (160 km on average within 30 days after ringing). This species, therefore, has potentially increased dispersal abilities for HP AIV than mallard and Eurasian pochard. Common teal may cover long distances within a few days, potentially acting as efficient virus carriers. For instance, one bird in our ringing dataset covered $640 \mathrm{~km}$ in 2 days, from Camargue to Austria. However, ducks will not be such efficient vectors if the virus inhibits their capacities to move (Rodrigues et al., 2006; van Gils et al., 2007; Weber and Stilianakis, 2007; Lebarbenchon et al., 2009). In contrast, mallard and Eurasian pochard were observed to cover shorter distances in this study. Respectively, 94\% and 96\% of recoveries were within $100 \mathrm{~km}$ of the ringing site 

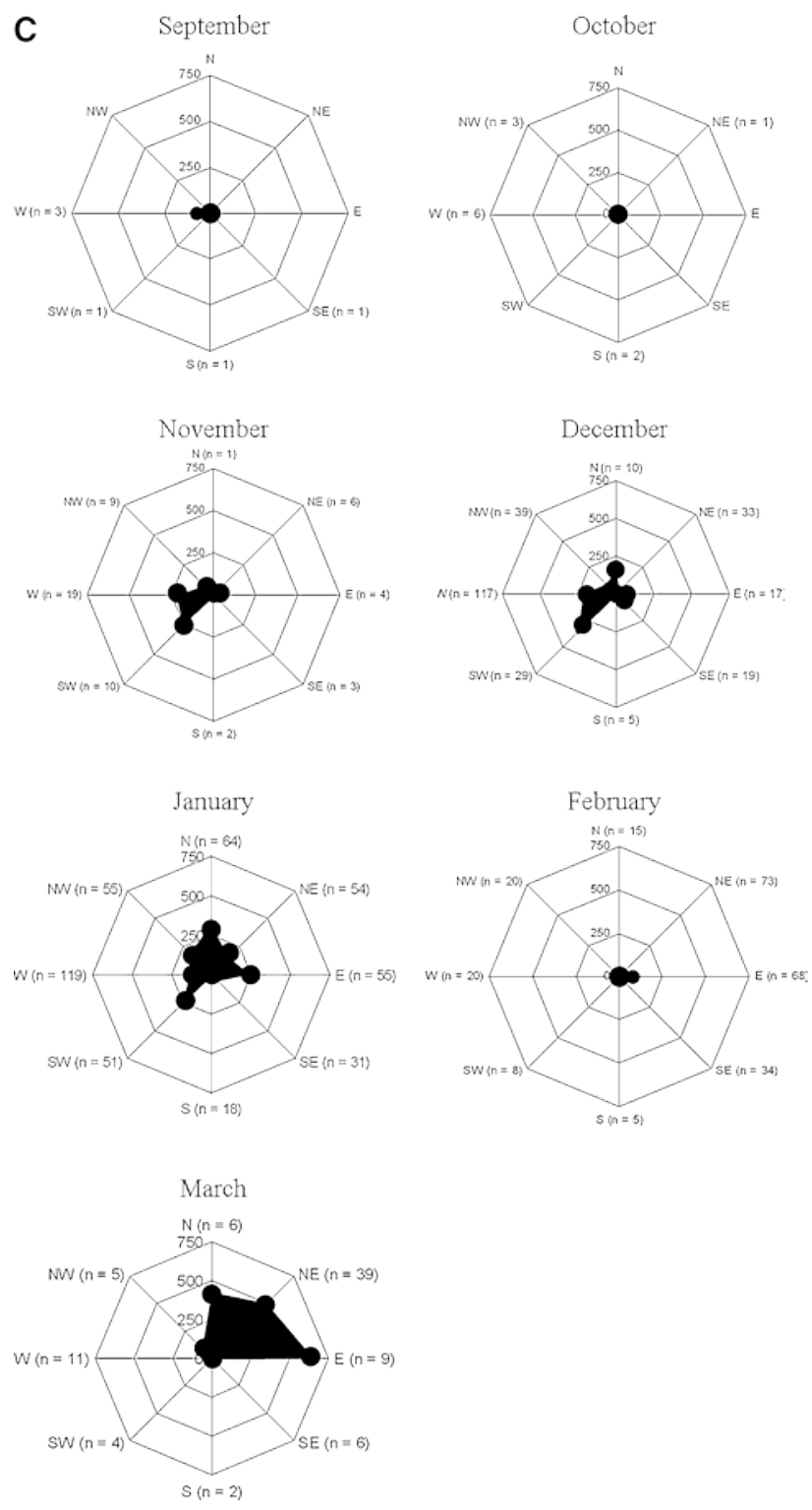

Figure 1. continued

Table 1. Results of the stepwise backwards procedure for the GLM

\begin{tabular}{lllll}
\hline Variables & Estimate & SE & t values & $P$ values \\
\hline Duck species & 0.871 & 0.117 & 7.429 & $<0.001$ \\
Month of ringing & 0.216 & 0.036 & 6.048 & $<0.001$
\end{tabular}

The complete model included duck species, month and year of ringing. Only the variables included in the final model are presented. The final model provided a good fit to the data (see text).

throughout the winter. Mallard is a more sedentary species than the two other (Cramp and Simmons, 1977). The Eurasian pochard sample size was considerably smaller than the other two species, and this species is known to often travel longer distances than observed in our study (e.g., more than $200 \mathrm{~km}$ in 1 month; Keller et al., 2009). Whatever the distance they cover, the three duck species apparently move in any direction during the core of the winter (from November to January), which is consistent with the known high turnover rate within the wintering population of common teal (Pradel et al., 1997). Although it has not yet been demonstrated, such a turnover is also likely to exist for mallard and Eurasian pochard. Thus, the risk area for HP AIV dispersal extends on average 25, 30, and $160 \mathrm{~km}$ beyond the Camargue throughout the wintering season and until 30 days after ringing, for Eurasian pochard, mallard, and common teal, respectively. In February and March, all three species tended to move toward the North-East. This is consistent with the beginning of the spring migration in February in common teal (Guillemain et al., 2006). Most individuals were migrating back to their breeding areas in Northern and North-Eastern Europe during this period (Scott and Rose, 1996).

To determine the potential risk of HP AIV dispersal by ducks more precisely, bird movements will have to be linked with data on virus excretion and persistence in the water (Lebarbenchon et al., 2009). Recent studies experimentally infected wild ducks with HP H5N1 AIV and, based on viral excretion duration, concluded that migratory ducks have an important role for AIV spread (Keawcharoen et al., 2008). There is however evidence that even LP AIV can impair foraging and dispersal efficiency of infected birds in the wild (van Gils et al., 2007; LatorreMargalef et al., 2009). Although infected birds might be able to transmit HP AIV over short distances, more realistic experiments, using birds subjected to physiological stresses associated with migration, are needed to determine their capacity to spread viruses over long distances during their winter movements (Weber and Stilianakis, 2007). On the other hand, a better scenario would be to have satellite tracking data on both known infected and uninfected individuals (controls), so that differences in flight distances and stopover durations could be measured and statistically evaluated in the wild. Combination of data on virus excretion, persistence in the environment, and wild duck dispersal also remain critical to determine potential AIV dispersal accurately (Breban et al., 2009; Lebarbenchon et al., 2009; Roche et al., 2009).

Ringing-recovery data can only provide limited information. The exact route of migration is not known from the recovery location of ringed birds but has to be esti- 


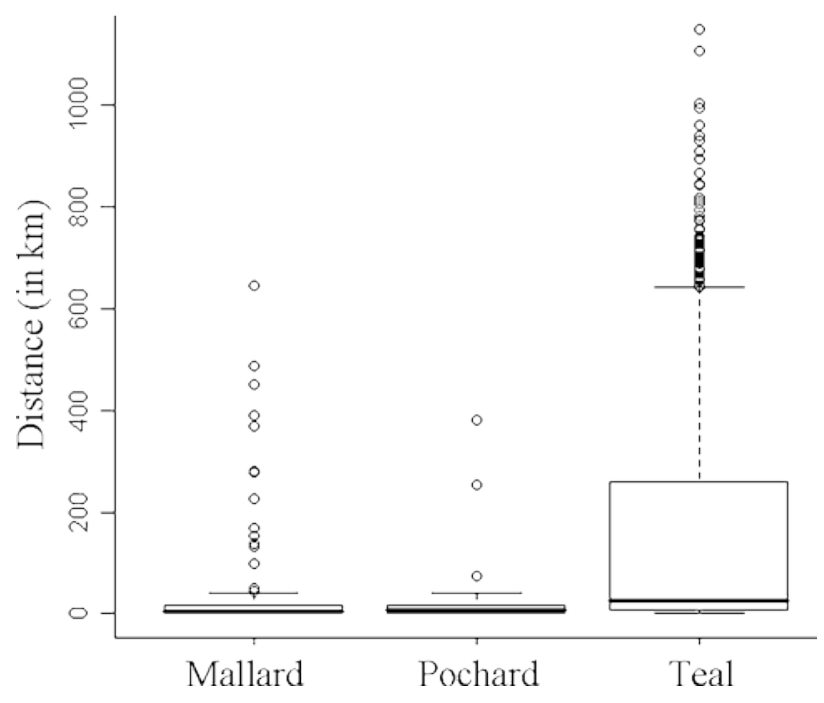

Figure 2. Median distance covered by mallard, Eurasian pochard, and common teal in winter, between ringing at the Tour du Valat in Camargue and the recovery date.

mated (Gauthier-Clerc and Le Maho, 2001). Migrating birds rarely fly the full distance between breeding and wintering areas, or between two distant wetlands, without stopping over and "refuelling" or resting along the way (Guillemain et al., 2004 for Garganey Anas querquedula). Instead, birds make frequent stopovers and spend more time eating and preparing for movements than actively performing flights (Alerstam, 1990). Many species therefore aggregate at favorable stopover or wintering sites, resulting in high local densities. When all of these sites are taken into account, the number of wetlands that could potentially become infected with HP AIV increases dramatically.

Our study relies on intense data collection in the past, and we cannot rule out the possibility that migratory

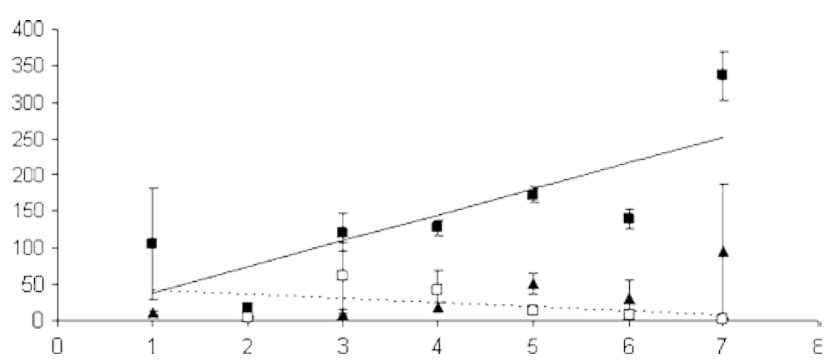

Figure 3. Mean distance (in $\mathrm{km}$ ) covered in 30 days after ringing according to wintering month for mallard (black triangles), common teal (black squares), and Eurasian pochard (white squares). Regression lines are shown where significant (common teal: plain line; Eurasian pochard: dotted line). Error bars indicate \pm standard error.
Table 2. Percentage of recoveries outside the Camargue (i.e., at a distance $>20 \mathrm{~km}$ from the ringing site), for each month and duck species

\begin{tabular}{lcll}
\hline Month & Mallard & Pochard & Teal \\
\hline September & 9.09 & No data & 50.00 \\
October & 21.43 & 0.00 & 14.29 \\
November & 13.89 & 25.00 & 46.77 \\
December & 17.74 & 33.33 & 48.40 \\
January & 29.82 & 16.67 & 61.15 \\
February & 6.67 & 11.11 & 50.19 \\
March & 14.29 & 0.00 & 63.86 \\
Total & 19.31 & 17.39 & 54.18 \\
\hline
\end{tabular}

The month given refers to the month of ringing. Recoveries were made within 30 days and no later than March 31.

behavior of ducks wintering in the Camargue has changed to some extent since then in response to temperature increases or other aspects of global change (Svazas et al., 2001). In our study site, however, common teal population size and wintering phenology has not undergone significant changes since the $1970 \mathrm{~s}$ (Kayser et al., 2008). Recent monitoring (since 2002) of common teal ringed in the Camargue and fitted with nasal saddles also shows that common teal movements remain similar to those observed in the past (Guillemain et al., unpublished data).

Our analysis of duck movements (distance and direction) allows identification of the surrounding high-risk areas if an HP AIV outbreak occurs in the Camargue. A large part of southern France is potentially a high-risk zone of infection from September to October. In addition to France, northern Italy and northern Spain also become at risk from November to January. Then, in February and March, birds start to migrate to northern Europe and Siberia and the higher-risk areas are the southeast of France, northern Italy, and Switzerland. Thus, ducks from the Camargue can potentially infect major wetlands they use as wintering areas or as migratory stopovers, such as the Dombes (France), the Ebro delta (Spain), the Pô delta (Italy), and the alpine lakes (Switzerland). A similar pattern is expected if an outbreak occurs in another western Mediterranean wetland, because these lie within the same flyway as the Camargue (Guillemain et al., 2005). Consequently all wetlands around any site in the western Mediterranean area in which an outbreak occurs are potential high-risk areas at least during some parts of the wintering period. Moreover, distances travelled by duck were prob- 
ably underestimated in our study, because most recoveries were provided by hunters and shot birds may have travelled farther if they had not been stopped.

\section{CONCLUSIONS}

The maximal potential distance of HP AIV dispersal varied according to duck species and month. If an outbreak occurs in the Camargue in winter, during the next month, HP AIV can be transported at a maximal distance of $<100 \mathrm{~km}$ by mallard and Eurasian pochard and at a distance $>100 \mathrm{~km}$ by common teal. In terms of the high-risk azimuths, in September and October, southern France is the principal risk area. From November to January, all azimuths are at risk. Finally, in February or March, north-east is the direction at greatest risk.

\section{ACKNOWLEDGMENTS}

The authors are most grateful to Luc Hoffmann, Hubert Kowalski, Heinz Hafner, Alan Johnson, and others who ringed ducks at the Tour du Valat for 25 years. We also thank Marc Lutz, Paul Isenmann, and the Centre de
Recherche sur la Biologie des Populations d'Oiseaux (Muséum National d'Histoire Naturelle, Paris) for their help computerizing the Tour du Valat ringing database. Two anonymous referees provided useful comments on an earlier version of the manuscript. A.L. Brochet was funded by a Doctoral grant from Office National de la Chasse et de la Faune Sauvage, with additional funding from a research agreement between ONCFS, the Tour du Valat, Laboratoire de Biométrie et de Biologie Evolutive (UMR 5558 CNRS Université Lyon 1) and the Doñana Biological Station (CSIC). Camille Lebarbenchon was supported by a "Région Languedoc-Roussillon - Tour du Valat" PhD grant during this study. This work also received funding from the Agence Nationale de la Recherche through the Santé Environnement - Santé Travail scheme (contract number 2006-SEST-22), the European Union's Framework Program for Research and Technological Development (FP6) (NEW-FLUBIRD project, contract number FP6-2005SSP5B Influenza), and from the Agence Interorganisme pour la Recherche et le Développement.

\section{APPENDIX}

Median distance (D in km) and azimuth (A in decimal degrees) of recoveries for mallard (a), Eurasian pochard (b), and common teal (c), ringed during each month of the winter. Numbers in brackets give minimum and maximum values. Note that sample size (n) may be lower for azimuth than for distance travelled because, when birds were recovered at the ringing site itself, distance $=0$ but azimuth could not be computed.

\begin{tabular}{|c|c|c|c|c|}
\hline \multirow[t]{2}{*}{ Month } & & \multicolumn{3}{|l|}{ No. of days since ringing } \\
\hline & & $0-10$ days & 11-20 days & 21-30 days \\
\hline \multicolumn{5}{|l|}{ (a) } \\
\hline \multirow[t]{2}{*}{ September } & $\mathrm{D}$ & $11.0(0.0 / 19.6), n=7$ & $14.6(0.0 /, 20.7) n=4$ & No data \\
\hline & A & $-90.0(-106.4 / 144.3), n=5$ & $-51.1(-51.1 / 144.0), \mathrm{n}=3$ & No data \\
\hline \multirow[t]{2}{*}{ October } & $\mathrm{D}$ & $7.8(0.0 / 24.0), n=8$ & $10.1(5.5 / 45.1), n=3$ & 7.7 (5.5/7.7), $n=3$ \\
\hline & A & $111.5(-89.9 / 111.5), \mathrm{n}=5$ & $47.4(23.5 / 47.4), n=3$ & $44.1(44.0 / 47.4), n=3$ \\
\hline \multirow[t]{2}{*}{ November } & $\mathrm{D}$ & $0.0(0.0 / 20.6), n=19$ & $8.6(0.0 / 30.3), n=14$ & $0.0(0.0 / 18.3), n=3$ \\
\hline & A & $154.2(-90.0 / 154.2), \mathrm{n}=9$ & $-90.0(-90.0 / 154.2), \mathrm{n}=11$ & $144.0, n=1$ \\
\hline \multirow[t]{2}{*}{ December } & $\mathrm{D}$ & $3.3(0.0 / 225.5), \mathrm{n}=35$ & $2.7(0.0 / 134.9), n=13$ & $3.9(0.0 / 153.1), n=14$ \\
\hline & A & $-90.0(-137.8 / 180.0), \mathrm{n}=23$ & $-90.0(-114.7 /-23.5), \mathrm{n}=10$ & $115.0(-115.3 / 144), n=10$ \\
\hline \multirow[t]{2}{*}{ January } & $\mathrm{D}$ & $7.9(0.0 / 369.5), n=24$ & $11.0(0.0 / 450.7), \mathrm{n}=18$ & $11.1(0.0 / 488.4), \mathrm{n}=15$ \\
\hline & A & $-175.9(-160.0 / 168.3), \mathrm{n}=18$ & $149.8(-90.0 / 149.8), n=15$ & $149.8(-106.4 / 154.2), \mathrm{n}=12$ \\
\hline \multirow[t]{2}{*}{ February } & $\mathrm{D}$ & $2.7(0.0 / 19.1), n=7$ & $1.3(0.0 / 5.5), \mathrm{n}=6$ & 201.2 (10.7/391.8), $n=2$ \\
\hline & A & $-90.0(-144.0 / 39.1), \mathrm{n}=6$ & $-90.0(-90.0 / 47.4), \mathrm{n}=4$ & 98.7 (47.6/149.8), $n=2$ \\
\hline \multirow[t]{2}{*}{ March } & $\mathrm{D}$ & $2.3(0.0 / 644.9), n=7$ & No data & No data \\
\hline & A & $141.9(-144.0 / 67.9), \mathrm{n}=4$ & No data & No data \\
\hline
\end{tabular}


continued

\begin{tabular}{|c|c|c|c|c|}
\hline \multirow[t]{2}{*}{ Month } & & \multicolumn{3}{|l|}{ No. of days since ringing } \\
\hline & & $0-10$ days & 11-20 days & 21-30 days \\
\hline \multicolumn{5}{|l|}{ (b) } \\
\hline \multirow[t]{2}{*}{ September } & $\mathrm{D}$ & No data & No data & No data \\
\hline & A & No data & No data & No data \\
\hline \multirow[t]{2}{*}{ October } & $\mathrm{D}$ & $4.6, n=1$ & No data & No data \\
\hline & A & $-35.9, \mathrm{n}=1$ & No data & No data \\
\hline \multirow[t]{2}{*}{ November } & $\mathrm{D}$ & $16.3(6.2 / 20.9), n=5$ & 16.3 (16.3/16.3), $n=2$ & $382.5, \mathrm{n}=1$ \\
\hline & A & $-55.3(-105.3 / 154.2), n=5$ & $-55.3(-55.3 /-55.3), n=2$ & $-78.9, n=1$ \\
\hline \multirow[t]{2}{*}{ December } & $\mathrm{D}$ & $9.2(3.3 / 74.2), \mathrm{n}=5$ & 2.7 (1.9/252.4), $\mathrm{n}=3$ & 4.6, $\mathrm{n}=1$ \\
\hline & A & $154.2(-105.3 / 154.2), n=4$ & $2.9(-90.0 / 2.9), \mathrm{n}=3$ & $-35.9, \mathrm{n}=1$ \\
\hline \multirow[t]{2}{*}{ January } & $\mathrm{D}$ & $11.3(0.0 / 19.7), \mathrm{n}=6$ & 12.7 (4.6/20.9), $\mathrm{n}=4$ & $19.8(0.0 / 39.7), n=2$ \\
\hline & A & $-54.3(-160.1 /-48.6), \mathrm{n}=4$ & $-70.971 .1(-105.3 /-35.9), n=4$ & $-79.1, n=1$ \\
\hline \multirow[t]{2}{*}{ February } & $\mathrm{D}$ & $1.9(0.0 / 14.8), n=5$ & $0.0 \mathrm{n}=1$ & $17.6(3.3 / 20.7), n=3$ \\
\hline & A & $89.9(-55.4 / 89.9), n=3$ & No data & $55.4(-51.1 / 55.4), \mathrm{n}=3$ \\
\hline \multirow[t]{2}{*}{ March } & $\mathrm{D}$ & $0.7(0.0 / 2.7), \mathrm{n}=4$ & $0.9(0.0 / 1.9), n=2, n=1$ & $6.2, n=1$ \\
\hline & A & $-90.0, \mathrm{n}=1$ & No data & $-25.8, n=1$ \\
\hline \multicolumn{5}{|l|}{ (c) } \\
\hline \multirow[t]{2}{*}{ September } & $\mathrm{D}$ & $11.4(4.4 / 18.3), \mathrm{n}=2$ & 32.6 (13.2/51.9), $n=2$ & 268.8 (54.6/483.6), $n=2$ \\
\hline & A & $-165.3(-114.7 / 144.0), n=2$ & $-135.6(-79.5 / 168.3), n=2$ & $-80.3(-84.6 /-75.9), n=2$ \\
\hline \multirow[t]{2}{*}{ October } & $\mathrm{D}$ & $8.3(0.0 / 99.1), n=8$ & $10.9(2.7 / 18.6), n=5$ & 2.7, $n=1$ \\
\hline & A & $-95.7(-101.5 / 168.3), n=6$ & $-90.0(-90.0 / 168.3), \mathrm{n}=5$ & $-90.0, \mathrm{n}=1$ \\
\hline \multirow[t]{2}{*}{ November } & $\mathrm{D}$ & $2.5(0.0 / 26.4), n=18$ & $165.8(0.0 / 1149.1), \mathrm{n}=18$ & 169.3 (2.7/482.9), $n=26$ \\
\hline & A & $-144.0(-144.0 / 154.2), \mathrm{n}=11$ & $-92.7(-104.1 / 88.1), \mathrm{n}=17$ & $-115.3(-138.1 / 173.1), n=26$ \\
\hline \multirow[t]{2}{*}{ December } & $\mathrm{D}$ & $6.7(0.0 / 911.0), \mathrm{n}=169$ & $146.3(0.0 / 578.5), \mathrm{n}=103$ & $216.1(0.0 / 1004.0), \mathrm{n}=71$ \\
\hline & A & $-103.3(-144 / 180.0), n=107$ & $-99.4(-151.0 / 171.7), \mathrm{n}=94$ & $-93.7(-139.2 / 171.1), \mathrm{n}=68$ \\
\hline \multirow[t]{2}{*}{ January } & $\mathrm{D}$ & 24.2 (0.0/807.9), $n=200$ & $171.9(0.0 / 940.7), \mathrm{n}=128$ & $252.1(0.0 / 894.4), n=143$ \\
\hline & A & $-117.7(-160.0 / 173.1), \mathrm{n}=192$ & $-125.3(-162.1 / 173.1), n=118$ & $161.2(-141.8 / 168.3), \mathrm{n}=136$ \\
\hline \multirow[t]{2}{*}{ February } & $\mathrm{D}$ & $18.6(0.0 / 843.1), \mathrm{n}=155$ & $170.7(0.0 / 726.6), n=57$ & $282.1(0.0 / 738.7), n=53$ \\
\hline & A & $95.5(-160.0 / 168.3), n=139$ & $90.7(-144.0 / 168.3), n=54$ & $73.4(-160.0 / 180), n=51$ \\
\hline \multirow[t]{2}{*}{ March } & $\mathrm{D}$ & $22.8(2.1 / 711.4), n=43$ & $416.2(0.0 / 1107.1), \mathrm{n}=29$ & 424.9 (2.3/930.7), $n=11$ \\
\hline & A & $75.7(-144.7 / 171.7), n=43$ & $66.4(-144.0 / 154.2), n=28$ & $64.9(-144.0 / 173.1), n=11$ \\
\hline
\end{tabular}

\section{REFERENCES}

Alerstam T (1990) Bird Migration, Cambridge: Cambridge University Press

Breban R, Drake JM, Stallknecht DE, Rohani P (2009) The role of environmental transmission in recurrent avian influenza epidemics. PLoS Computational Biology 5:e1000346

Brown JD, Stallknecht DE, Beck JR, Suarez DL, Swayne DE (2006) Susceptibility of North American ducks and gulls to H5N1 highly pathogenic avian influenza viruses. Emerging Infectious Diseases 12:1663-1670

Bub H (1991) Bird Trapping and Bird Banding: A Handbook for Trapping Methods all Over the World, New York: Cornell University Press

Cramp S, Simmons KEL (1977) Handbook of the Birds of Europe the Middle East and North Africa, the Birds of Western Paleartic, Volume 1 Ostrich to Ducks, Oxford: Oxford University Press
Crawley MJ (1993) Glim for Ecologists, Oxford: Blackwell Scientific Publications

De Marco MA, Foni E, Campitelli L, Raffini E, Delogu MDonatelli I (2003) Long-term monitoring for avian influenza viruses in wild bird species in Italy. Veterinary Research Communications 27(Suppl 1):107-114

Delany S, Scott D (2006) Waterbird Population Estimates, 4 ed., Wageningen: Wetlands International

Feare CJ (2007) The role of wild birds in the spread of HPAI H5N1. Avian Diseases 51:440-447

Gauthier-Clerc M, Le Maho Y (2001) Beyond bird marking with rings. Ardea 89:221-230

Gauthier-Clerc M, Lebarbenchon C, Thomas F (2007) Recent expansion of highly pathogenic avian influenza H5N1: a critical review. Ibis 149:202-214

Gilbert M, Xiao X, Domenech J, Lubroth J, Martin V, Lubroth J, et al. (2006) Anatidae migration in the western Palearctic and 
spread of highly pathogenic avian influenza H5N1 virus. Emerging Infectious Diseases 12:1650-1656

Globig A, Staubach C, Beer M, Köppen U, Fiedler W, Nieburg M, et al. (2009) Epidemiological and ornithological aspects of outbreaks of highly pathogenic avian influenza virus H5N1 of Asian lineage in wild birds in Germany, 2006 and 2007. Transboundary and Emerging Diseases 56:57-72

Green AJ (1996) Analyses of globally threatened Anatidae in relation to threats, distribution, migration patterns, and habitat use. Conservation Biology 10:1435-1445

Guillemain M, Arzel C, Mondain-Monval JY, Schricke V, Johnson AR, Simon G (2006) Spring migration dates of teal Anas crecca ringed in the Camargue, southern France. Wildlife Biology 12:163-169

Guillemain M, Fritz H, Klaassen M, Johnson AR, Hafner H (2004) Fuelling rates of Garganey (Anas querquedula) staging in the Camargue, southern France, during spring migration. Journal of Ornithology 145:152-158

Guillemain M, Sadoul N, Simon G (2005) European flyway permeability and abmigration in Teal Anas crecca, an analysis based on ringing recoveries. Ibis 147:688-696

Hulse-Post DJ, Sturm-Ramirez KM, Humberd J, Seiler P, Govorkova EA, Krauss S, et al. (2005) Role of domestic ducks in the propagation and biological evolution of highly pathogenic H5N1 influenza viruses in Asia. Proceedings of the National Academy of Sciences of the USA 102:10682-10687

Jourdain E, Gauthier-Clerc M, Bicout DJ, Sabatier P (2007) Bird migration routes and risk for pathogen dispersion into western Mediterranean wetlands. Emerging Infectious Diseases 13:365372

Kayser Y, Gauthier-Clerc M, Béchet A, Poulin B, Massez G, Chérain Y, et al. (2008) Compte rendu ornithologique camarguais pour les années 2001-2006 [in French]. Revue d'Ecologie (Terre Vie) 63:299-349

Keawcharoen J, van Riel D, van Amerongen G, Besteboer T, Beyer WE, van Lavieren R, et al. (2008) Wild ducks as long-distance vectors of highly pathogenic avian influenza. Emerging Infectious Diseases 14:600-607

Keller I, Korner-Nievergelt F, Jenni L (2009) Within-winter movements: a common phenomenon in the Common Pochard Aythya ferina. Journal of Ornithology 150:483-494

Kilpatrick AM, Chmura AA, Gibbons DW, Fleischer RC, Marra P, Daszak P (2006) Predicting the global spread of H5N1 avian influenza. Proceedings of the National Academy Sciences of the USA 103:19368-19373

Latorre-Margalef N, Gunnarson G, Munster VJ, Fouchier RAM, Osterhaus ADME, Elmberg J, et al. (2009) Effects of influenza A virus infection on migrating mallard ducks. Proceedings of the Royal Society B 276:1029-1036

Lebarbenchon C, Albespy F, Brochet AL, Grandhomme V, Renaud F, Fritz H, et al. (2009) Spread of avian influenza viruses by Common Teal (Anas crecca) in Europe. PLoS ONE 4:e7289

Lebarbenchon C, Chang CM, Grandhomme V, Dietrich M, Kayser $\mathrm{Y}$, Elguero $\mathrm{E}$, et al. (in press) Avian influenza circulation in the Camargue (south of France) during the 2006-2007 season. Avian Diseases
Lebarbenchon C, van der Werf S, Thomas F, Aubin JT, Azebi S, Cuvelier F, et al. (2007) Absence of detection of highly pathogenic H5N1 in migratory waterfowl in southern France in 20052006. Infection, Genetics and Evolution 7:604-608

Nagy A, Vostinakova V, Pindova Z, Hornickova J, Cernikova L, Sedlak K, et al. (2009) Molecular and phylogenetic analysis of the H5N1 avian influenza virus caused the first highly pathogenic avian influenza outbreak in poultry in the Czech Republic in 2007. Veterinary Microbiology 133:257-263

Olsen B, Munster VJ, Wallensten A, Waldenström J, Osterhaus ADME, Fouchier RAM (2006) Global patterns of influenza A virus in wild birds. Science 312:384-388

Pradel R, Rioux N, Tamisier A, Lebreton JD (1997) Individual turnover among wintering teal in Camargue: a mark-recapture study. Journal of Wildlife Management 61:816-821

R Development Core Team (2008) R: a language and environment for statistical computing-R Foundation for Statistical Computing, Vienna, Austria. ISBN 3-900051-07-0, URL: http://www. R-project.org

Ridgill SC, Fox AD (1990) Cold weather movements of waterfowl in western Europe. Slimbridge: IWRB Publication 13

Roche B, Lebarbenchon C, Gauthier-Clerc M, Chang CM, Thomas F, Renaud F, et al. (2009) Water-borne transmission drives avian influenza dynamics in wild birds: the case of the 20052006 epidemics in the Camargue area. Infection, Genetics and Evolution 9:800-805

Rodrigues D, Figueiredo ME, Fabiao A, Encarnaçao V (2006) Ducks and the risk of avian influenza in Portugal. Airo 16:69-74

Scott DA, Rose PM (1996) Atlas of Anatidae populations in Africa and Western Eurasia, Wageningen: Wetlands International

Sturm-Ramirez KM, Hulse-Post DJ, Govorkova EA, Humberd J, Seiler P, Puthavathana P, et al. (2005) Are ducks contributing to the endemicity of highly pathogenic H5N1 influenza virus in Asia? Journal of Virology 79:11269-11279

Svazas S, Meissner W, Serebryakov V, Kozulin A, Grishanov G (2001) Changes of Wintering Sites of Waterfowl in Central and Eastern Europe. Vilnius: Oiseaux Migrateurs du Paléarctique Occidental "OMPO Vilnius" and Lithuanian Institute of Ecology

Tamisier A, Dehorter O (1999) Camargue, Ducks and Coots. Functioning and Gradual Change of a Prestigious Wintering Ground [in French]. Nîmes: Centre Ornithologique du Gard

van Gils JA, Munster VJ, Radersma R, Liefhebber D, Fouchier RAM, Klaassen M (2007) Hampered foraging and migratory performance in swans infected with low-pathogenic avian influenza A virus. PLoS One 1:e184

Weber TP, Stilianakis NI (2007) Ecologic immunology of avian influenza (H5N1) in migratory birds. Emerging Infectious Diseases 13:1139-1143

Webster RG, Bean WJ, Gorman OT, Chambers TM, Kawaoka Y (1992) Evolution and ecology of influenza A viruses. Microbiological Reviews 56:152-179 